Humanities and Social Sciences

HSS, vol. XVIII, 20 (4/2013), pp. 47-62

2013

\author{
Cezary KOŚCIELNIAK ${ }^{1}$
}

\title{
PUBLICZNE ROLE WSPÓŁCZESNEGO UNIWERSYTETU: MIĘDZY ZOBOWIĄZANIAMI KULTUROWYMI A EKONOMICZNYMI ${ }^{2}$
}

\begin{abstract}
Celem artykułu jest zaprezentowanie analizy przemian zobowiązań publicznych uniwersytetu, szczególnie w ich dwóch wymiarach: kulturowych i ekonomicznych. W ostatnich pięćdziesięciu latach uniwersytety świata Zachodniego przechodziły przez „przedsiębiorczą zmianę”. Ich misja była zorientowana na produkcję wiedzy połączoną z procesami komercjalizacji wiedzy. Tym samym, instytucje wiedzy spełniają istotne funkcje w kształtowaniu społeczeństwa dobrobytu, zarówno $\mathrm{w}$ wymiarze edukacyjnym, jak i badawczym. Jednocześnie krytycy rozpoczętej przez Clarka Kerra „przedsiębiorczej zmiany” w Stanach Zjednoczonych w latach 60 wskazują, że była ona źródłem kryzysu publicznych zobowiązań uniwersytetu, ograniczając je jedynie do perspektywy ekonomicznej. Zarówno liberalni i konserwatywni krytycy są zgodni co do znaczącej roli humanistyki we współczesnym uniwersytecie, która ma uzupełniać kształcenie profesjonalne. Artykuł pokazuje potencjalne możliwości poszerzenia publicznych zobowiązań $\mathrm{w}$ postaci polityk zrównoważonego rozwoju, polityk zmniejszania nierówności czy - używając terminu Marty Nussbaum - poszerzania instytucjonalnego zaangażowania uczelni w procesach global citizenship. Zobowiązania uniwersytetu wobec sfery publicznej łączą ze sobą kwestie kulturowe z ekonomicznymi. Przykładem wspólnego zadania może być rola uniwersytetu w wyrównywaniu nierówności społecznych, poprzez zwiększanie dostępu do instytucji wiedzy. Konkluzją tekstu jest postulat wzajemnego uznania zobowiązań ekonomicznych i kulturowych oraz ich wzajemnej synchronizacji. Ważne jest jednak ukazanie protokołu rozbieżności między dwoma podejściami.
\end{abstract}

Słowa kluczowe: uniwersytet, publiczne zobowiązania, rozwój społeczny

\section{KONTEKSTY DLA ZMIANY PUBLICZNYCH RÓL INSTYTUCJI WIEDZY}

W ostatnich dekadach społeczna rekonstrukcja klasycznej roli współczesnego uniwersytetu dokonała się już bardzo silnie pod wpływem nowych oczekiwań społecznych i okoliczności gospodarczych. Odniesieniem dla uniwersytetu stały się nowe wyzwania ekonomiczne, szczególnie model zachodniego państwa dobrobytu. Odbiorcy uczelni:

\footnotetext{
${ }^{1}$ Dr Cezary Kościelniak, Instytut Kulturoznawstwa, Uniwersytet im. Adama Mickiewicza w Poznaniu, Wydział Nauk Społecznych, ul. Szamarzewskiego 89a, 60-560 Poznań, e-mail: cezkos@ amu.edu.pl

${ }^{2}$ Artykuł powstał dzięki wsparciu Narodowego Centrum Nauki, projekt nr 2011/01/D/HS1/01752, „Dynamika publicznych zobowiązań współczesnego uniwersytetu w kontekście religii oraz społeczeństwa wielokulturowego. Analiza porównawcza i teoretyczna”.
} 
studenci, otoczenie gospodarcze, regiony, państwa, a nawet struktury międzynarodowe (jak Unia Europejska), wykształcili nowe oczekiwania wobec uniwersytetu. Oczekiwania te są ze sobą powiązane. Momentem pojawienia się zmiany zaś były lata sześćdziesiąte XX wieku, kiedy to uniwersytety przekształciły zarówno swoje role kulturowe (co wiązało się $\mathrm{z}$ rewolucją obyczajową oraz wzrostem dynamiki ruchów emancypacyjnych), jak i stanęły w obliczu nowych wyzwań ekonomicznych. W tym momencie tradycyjne zobowiązania, kształtowane w Europie (a częściowo także w Stanach Zjednoczonych), takie jak kształcenie i prowadzenie badań, zostały uzupełnione nowymi - tak zwaną trzecią misją, czyli służebnością wobec otoczenia.

Przełomową książką w tym procesie była pozycja Clarka Kerra The Uses of the University, która zapowiadała zmianę, jaką można by później określić „zmianą przedsiębiorczą” uniwersytetu. Powiązanie zmiany ekonomicznej z kulturową można zauważyć już na poziomie języka: uczelnie nie są instytucjami do „poszukiwania prawdy”, lecz „produkcji wiedzy", nie odgrywają już roli autorytetu publicznego, ale są elementem systemów ekonomicznych ${ }^{3}$. Innymi słowy, zmiana ekonomiczna pociągała za sobą silną zmianę nie tylko ekonomiczną, ale i kulturową. Jeśli rozważać tę kwestię z perspektywy klasycznej już pozycji Kazimierza Twardowskiego $O$ dostojeństwie uniwersytetu z 1938 roku, w której uniwersytet był porównany do dostojnej, oddalonej od świata latarni wyznaczającej horyzonty myślenia, to widać wyraźną różnicę, współcześnie nie ma miejsca na tak zdefiniowany uniwersytet ${ }^{4}$. Zestawienie głównych idei uniwersytetu Kerra i Twardowskiego - o czym będzie później mowa w tekście - pozwala zauważyć zasadniczą różnicę między celami i wizją uczelni.

Współczesna misja uczelni bardziej przypomina instytucję korporacyjną, gdzie uwspólnienie działań między lokalnym systemem ekonomicznym a uniwersytetem jest jednym $\mathrm{z}$ najbardziej istotnych sposobów jej funkcjonowania. Ma to odzwierciedlenie w hierarchii dyscyplin, gdzie na pierwszy plan wysuwają się dyscypliny ścisłe i techniczne, natomiast humanistyka i nauki społeczne pozostają w mniejszości. W tym kontekście uczelnia zmieniła swój wewnętrzny wizerunek: nie jest już jedynie instytucją przypominającą wszechnicę, miejscem wymiany poglądów, opinii, działania kontemplacyjnego czy mądrości filozoficznej ${ }^{5}$. Będzie ona raczej interaktywną strukturą, której zadania zostają wpisane $\mathrm{w}$ system ekonomiczny. Widocznym znakiem tej przemiany jest sposób określania potencjału uczelni. Nie mierzy się go już tylko liczbą publikacji czy zdobyciem prestiżowych nagród naukowych. Potencjał ten mierzy się również czynnikami, jakie stosuje się do przedsiębiorstw; miarą jest udział finansowy $\mathrm{w}$ grantach, dochody płynące $\mathrm{z}$ operacji $\mathrm{z}$ biznesem, liczba wyprodukowanych patentów. Na uczelniach specjalizujących się bardziej w procesie kształcenia niż badań miarą będą wpływy z opłat za studia oraz przełożenie

\footnotetext{
${ }^{3}$ Zob. T. Sławek, Antygona $w$ świecie korporacji. Rozważania o uniwersytecie $i$ czasach obecnych, Wydawnictwo Uniwersytetu Śląskiego, Katowice 2002.

${ }^{4}$ Zob. Reprint wykładu Kazimierza Twardowskiego $O$ dostojeństwie uniwersytetu został opublikowany pod takim tytułem przez Wydawnictwo UAM w $2012 \mathrm{r}$.

${ }^{5}$ Koncepcja uniwersytetu jako wszechnicy był jedną z dziewiętnastowiecznych koncepcji uniwersytetu, zob. J. H. Newman, Idea uniwersytetu, PAX, Warszawa 1991.
} 
kształcenia na praktykę zawodowa. Marek Kwiek $^{6}$ wskazuje na jeszcze jeden kontekst kulturowo-instytucjonalny oceny uniwersytetu: atrakcyjność jako miara jego oceny. Warto zwrócić uwagę na utylitarną zmianę: uniwersytet staje się miejscem produkcji wiedzy, patentów i ,wynalazków społecznych”, wymaga się od niego wywarzania mierzalnej wartości dodanej, a wypełnienie tego zadania kształtuje go jako instytucję atrakcyjną bądź nieatrakcyjną. Obecnie do atrakcyjności uczelni będzie należeć między innymi przełożenie edukacji na rynek pracy: wiele uczelni buduje swoją konkurencyjność, zaznaczając tempo tego przejścia i specjalizując się w kształceniu nie tylko wiedzy, ale i umiejętności. Inną zmianą jest otwarcie się na zewnętrznych interesariuszy: uczelnie coraz silniej nastawione są na działania wobec partnerów zamawiających badania czy podejmujących działania na rzecz rozwoju regionów oraz R\&D. Zmiana ta jednak doprowadza do transformacji samej struktury uczelni, która w takiej sytuacji staje się mocno zależna od swojego sponsora. Wreszcie można wskazać na „misję cywilną”, zaangażowanie uniwersytetów w programy pomocowe, na przykład wsparcie dla uczelni i studentów z krajów rozwijających się czy też udział w projektach związanych z edukacją ekologiczną ${ }^{7}$.

Zmiany te można nazwać ,przedsiębiorczymi” ${ }^{8}$, ,adaptacyjnymi” 9 . Określają one regionalną misję uczelni ${ }^{10}$ lub procesy transformacji ekonomicznej uczelni ${ }^{11}$. Nie można nie wspomnieć, że wywołują one sporą falę krytyki, jaką można znaleźć zarówno w literaturze zagranicznej, jak i w polskiej ${ }^{12}$. Głównym argumentem przeciw komercjalizacji instytucji wiedzy jest marginalizacja humanistyki, odejście od klasycznych zobowiązań uniwersytetu, ale także, o czym pisze Newfield, niewspółmierność podziałów zysków między uczelniami a korporacjami.

Bez wątpienia jednak wszyscy uczestniczy dyskusji o współczesnej roli uniwersytetu, jego zobowiązaniach oraz zmianie zgodzą się z następującymi punktami: (1) współczesna edukacja traktowana jest jako przepustka do dobrobytu, conditio sine qua non wejścia do świata lepszych możliwości życia; (2) społeczeństwo oparte na wiedzy traktuje edukację jako niezbędny element zmiany ekonomicznej; nowe wyzwania, takie jak elastyczny rynek pracy czy masowe użycie nowych technologii wymagają od społeczeństw bardziej zaawansowanego przygotowania, które dociera od nas właśnie ze strony edukacji; (3) określenie publicznych

\footnotetext{
${ }^{6}$ M. Kwiek M., Transformacje uniwersytetu, Wydawnictwo UAM, Poznań 2010.

${ }^{7}$ Zadania uczelni wobec wyzwań cywilizacyjnych, szczególnie powiązanych z kwestiami ekologicznymi można zauważyć na przykładzie zaangażowania uczelni w zrównoważony rozwój, zob. Sustainablity and Higher Education in Central and Eastern Europe, red. M. Adomssent, I. Otte, VAS, Bad Homburg 2013.

${ }^{8}$ Clark B., Creating Entrepreneurial University, Pergamon Press, New York 1998.

${ }^{9}$ Sporn B., Adaptive University Structures, „Higher education Policy” 1999, nr 54.

${ }^{10}$ P. Arbo, P. Benneworth Understanding the Regional Contribution of Higher Education Institutions, Paris: OECD, 2007.

${ }^{11}$ M. Kwiek, op. cit.

${ }^{12}$ Zob. T. Sławek, op. cit.; Ch. Newfield, Unmaking Public University, Harvard University Press, Harvard 2007; A. MacIntyre, God, Philosophy, Universities, Rowan\&Littlefield, Plymouth 2009, J. Sommerville, The Decline of Secular University, Oxford Univrsity Press 2005.
} 
zobowiązań uniwersytetu będzie wymagało odniesienia nie tylko do sfery ekonomicznej, ale także kulturowej.

Pytanie o kontekst publicznych zobowiązań uniwersytetu zachowuje podstawę kulturową: wobec kogo takie zobowiązania powinny być zrealizowane?

Pierwsza odpowiedź zostaje ukształtowana przez system ekonomiczny - rozwój państw i regionów, zapotrzebowanie na określony stopień rozwoju edukacji, wreszcie cel, jakim jest tworzenie społeczeństwa dobrobytu. Zobowiązania te mogą zostać określone warunkami ekonomicznymi. Kryzys ekonomiczny, uwarunkowania makropolityczne (w wypadku państw Unii Europejskiej, będą to zobowiązania państw członkowskich), ale także zmiany demograficzne są czynnikami kształtującymi cele uczelni. Jednak równocześnie z nimi pojawiają się nowe wyzwania dotyczące innowacji kulturowych, równie istotne w tym procesie. Tłem dla zmiany będzie również bardzo szybkie tempo transformacji ekonomicznych, a także zapotrzebowania na nowe funkcje społeczne. Jacek Sójka określa tę funkcję następująco: „Społeczna odpowiedzialność uniwersytetu oznacza, że jeśli uczelnia wyższa miałaby w czymś przypominać firmę, to właśnie w głębokim przemyśleniu własnej misji w obliczu nowych okoliczności. Jednocześnie rewolucja informatyczna, globalizacja i wewnętrzne reformy UE wymagają profesjonalnego zarządzania opartego na przemyślanej strategii" ${ }^{\prime \prime}$.

Bez wątpienia jednak problemem jest to, że określenie misji uniwersytetu dzisiaj, a co za tym idzie - zobowiązań, jakie on zaciąga, musi nastąpić zarazem w kontekście zmian ekonomicznych i kulturowych. Problem, z jakim się dzisiaj spotykamy, to próba przeciągania liny na jedną stronę. W niniejszym artykule zostaną przytoczone argumenty, które będą miały na celu pokazanie znaczenia obu tych czynników w kształtowaniu misji uczelni.

Role publiczne uniwersytetu będą rozumiane jako odpowiedź na działania podnoszące jakość życia społeczeństw. Innymi słowy, zawierają one w sobie organizację procesami ekonomicznymi, społecznymi i kulturowymi. Podkreślmy jednak, że problematyka tworzenia społeczeństwa dobrobytu $\mathrm{w}$ wymiarze ekonomicznym musi zawierać $\mathrm{w}$ sobie wymiar społeczny i kulturowy. Tym samym w niniejszych rozważaniach ukazane zostaną te dwa wymiary: kulturoznawczy oraz instytucjonalno-ekonomiczny. W tekście przedstawiono sfery zobowiązań, pierwsze $\mathrm{z}$ nich będą lokowane w sferze ekonomicznej. Tematem pierwszego punktu będzie ukazanie uwarunkowań instytucjonalnych instytucji wiedzy, a następnie określenie ich zobowiązań. W drugim zobrazowano kwestię kulturowych uwarunkowań szkolnictwa wyższego, co pozwoli na wydobycie kontekstów nowych formuł dla instytucji wiedzy.

13 J. Sójka, Spoleczna odpowiedzialność uniwersytetu, [w:] J. Sójka, A. Grzegorczyk, Fenomen uniwersytetu, Wydawnictwo UAM, Poznań 2008, s. 123. 


\section{PERSPEKTYWA ROZWOJOWA W KONTEKŚCIE KSZTALTOWANIA ZOBOWIĄZAŃ UNIWERSYTETU}

W literaturze przedmiotu edukacja staje się istotnym czynnikiem w rozwoju społecznym i ekonomicznym ${ }^{14}$. W podobnym tonie edukację traktują międzynarodowe instytucje, takie jak OECD czy Bank Światowy, gdzie edukacja pojawia się jako systemu społecznej stabilności, dobrobytu oraz wzrostu potencjału państw. Poszerzenie dostępu do wiedzy zostaje określone jako jeden $z$ głównych celów rozwojowych państw i społeczeństw. Jednocześnie proces ekonomicznego wzrostu powiązany jest $\mathrm{z}$ ewolucją praw obywatelskich, gdzie edukacja traktowana jest jako istotny czynnik wpływający na rozwój praw osobistych, a przy tym jest składnikiem postępu społecznego. Już samo ustawienie tych celów pokazuje znaczenie czynnika kulturowego: sama technologia rozwoju, oparta jedynie na mechanizmach ekonomicznych, nie jest wystarczająca, jeśli nie ma ona wsparcia $\mathrm{w}$ budowaniu dobrze wyedukowanego społeczeństwa, w którym jednostki mają swoje prawa. Myśl ta wydaje się banalna, jednakże praktyka polityk szkolnictwa wyższego, na przykład w Afryce czy w Chinach, dowodzi prób oparcia uczelni jedynie na mechanizmach rynkowych.

Polityka rozwojowa może zostać potraktowana jako punkt wyjścia dla zredefiniowania roli instytucji wiedzy, czyli tego elementu, który miałby wygenerować zobowiązania dla uniwersytetów.

Roczne raporty sprawozdawcze instytucji międzynarodowych, takich jak OECD (raport Education at Glance), pokazują wagę edukacji w systemach ekonomicznych państw, a jednocześnie pośrednio warunkują cele polityczne w tworzeniu społeczeństwa dobrobytu. Marius Busemeyer i Rita Nicolai w analizie tego problemu pokazują, że edukacja ma wpływ na kształtowanie się publicznych beneficjów: „Inwestycje w edukację kreują publiczne beneficja: wyższy poziom edukacji wpływa na produktywność oraz ekonomiczny dobrobyt społeczeństw, może być również istotnym instrumentem polityki społecznej do promowania

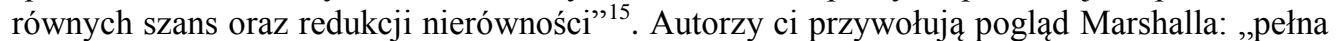
realizacja obywatelskich praw społecznych w sposób konieczny zawiera uniwersalne prawo do edukacji (prawo do bycia wyedukowanym) [...]"16. W perspektywie instytucjonalnej dążenie do spełnienia tego warunku oznacza poszerzanie wskaźnika scholaryzacji na etapie trzeciego stopnia kształcenia. Raport Education at Glance pokazuje dynamikę wzrostu scholaryzacji $\mathrm{w}$ ostatnich dwóch dekadach $\mathrm{w}$ grupie państw OECD: „Opierając się na obecnych wzorcach wejścia, przyjmuje się, że średnio 59\% z grupy młodych ludzi z krajów OECD zakwalifikuje się do programów edukacyjnych typu A (bazujących na teorii), natomiast $19 \%$ zakwalifikuje się do programów typu B (krótszych i o charakterze zawodowym)" ${ }^{\prime 17}$. Trend przewagi kształcenia teoretycznego pokazuje charakter uczelni w

\footnotetext{
${ }^{14}$ Zob. A. Sen, Wolność jako rozwój, Zysk i Ska, Poznań 1998; M. Kwiek, op. cit., B. Clark, op. cit.

${ }^{15}$ R.M. Busemeyer, R. Nikolai, Education, [w:] F. Castels, S. Leibfried, J. Lewis, H. Obinger, Ch. Pierson, The Oxford Handbook of Welfare State, Oxford University Press, Oxford 2010, s. 495.

${ }^{16}$ Ibidem, s. 496.

${ }^{17}$ OECD, Education at Glance 2011, Paris 2011.
} 
krajach wysokorozwiniętych, gdzie system szkolnictwa wyższego nie opiera się na kształceniu zawodowym.

Bez wątpienia perspektywa instytucjonalna ma silny związek z kreowaniem polityki rozwojowej ${ }^{18}$. Narzędziem bardziej precyzyjnym stosowanym przez OECD są raporty krajowe, pozwalające na ewaluację systemów i instytucji szkolnictwa wyższego w danych państwach. W raportach wymienia się sfery, takie jak: system szkolnictwa wyższego, szkolnictwo wyższe a rynek pracy, regionalna rola szkolnictwa wyższego, innowacje i badania, równość szans $\mathrm{w}$ dostępie do edukacji trzeciego stopnia, zasoby kadrowe, finansowanie, planowane i zarządzanie, jakość kształcenia oraz międzynarodowe aspekty szkolnictwa wyższego ${ }^{19}$. Jednak sam ten spis można potraktować jako zmianę oczekiwań instytucjonalnych od uczelni. Uczelnie muszą łączyć działania $\mathrm{w}$ kierunku poszerzenia rynków pracy $\mathrm{z}$ innowacyjnością, wymaganiami internacjonalizacyjnymi oraz sprawnym zarządzaniem. Biorąc pod uwagę kryterium coraz bardziej otwartego międzynarodowego rynku szkolnictwa wyższego, oczekiwania te bardzo silnie przypominają myślenie korporacyjne: wpływają one na zmianę struktury ich zarządzania, a co za tym idzie, pojawiają się nowe zachęty do zmian instytucjonalnych, mających na celu poprawienie efektywności wydawanych środków finansowych oraz samych instytucji. Aby uzyskać te cele, uczelnie, podobnie jak przedsiębiorstwa, na pewno muszą być świadome swoich celów i zobowiązań.

Perspektywa instytucjonalna rozwoju instytucji wiedzy bezpośrednio przenosi się na pole polityki rozwojowej. Warto zauważyć, że przytoczone opinie nie opierają się jedynie na stwierdzeniach normatywnych. Adam Szirmai, zestawiając związki edukacji z rozwojem społecznym, wskazuje na następujące walory: umiejętności profesjonalne, umiejętności rynkowe i finansowe, otwarcie na innowacje, wiedza o funkcjonowaniu rynku, a także dodaje zmianę w postawach (change in attitudes), definiowaną jako zmianę ,percepcji alternatyw”"20. Edukacja $\mathrm{z}$ jednej strony staje się podstawą do rozwijania dobrobytu poprzez umiejętności, $\mathrm{z}$ drugiej strony buduje potencjał intelektualny i etyczny, przede wszystkim kładąc nacisk na jej znaczenie. Jako mierzalne czynniki rozwoju podaje się $\mathrm{w}$ tym miejscu tendencje $\mathrm{w}$ analfabetyzmie, procencie dostępu do edukacji oraz nierównościach w dostępie do edukacji czy w relacji pomiędzy edukacją a rynkiem pracy. Państwa, dla których rozwój wiedzy stał się jednym z priorytetów, doprowadziły do znacznego spadku analfabetyzmu. Przykładowo w Indiach $\mathrm{w}$ latach pięćdziesiątych XX wieku odsetek analfabetów wynosił $80 \%$, w dziewięćdziesiątych $-50 \%$, a w roku 2000 - 43\%. Dla porównania w Turcji, w latach

\footnotetext{
${ }^{18}$ Tylko w Unii Europejskiej polityka ta kierowana jest do państw rozwijających się. Polska jest zaangażowana w Partnerstwo Wschodnie mające na celu niesienie pomocy krajom dawnego Związku Radzieckiego, natomiast jednym z priorytetów UE będzie Southern Partnership, skierowany na kraje Afryki Północnej. Działania pomocowe angażują kwestie edukacyjne, również instytucje uniwersytetu. Zob. C. Kościelniak, "Does European higher education policy could be a political tool for solidarity with South?", w: 10 years of Slovak Aid, Bratislava 2013.

19 Szczegółowy opis poszczególnych wymagań OECD zob. M. Dąbrowa-Szefler, J. Jabłecka, Szkolnictwo wyższe w Polsce. Raport dla OECD. MNiSW, Warszawa 2007.

${ }^{20}$ A. Szirmai, The Dynamic of Socio-Economic Development, Cambridge University Press, Cambridge 2005, s. 217.
} 
pięćdziesiątych wynosił 68\%, w dziewięćdziesiątych - 7\%, a w 2000 - 4\%. Według UNESCO średnia dynamika walki $\mathrm{z}$ analfabetyzmem dla krajów rozwijających się wynosiła w latach sześćdziesiątych 55\%, w dziewięćdziesiątych $-27 \%$, a w 2000 roku $-20 \%{ }^{21}$. Bez wątpienia dane te pokazują, jak olbrzymią pracę wykonały instytucje wiedzy, przede wszystkim szkoły, ale także podkreśla to priorytet edukacji jako czynnika rozwojowego. Oprócz rozwoju ekonomicznego edukacja silnie wpływa na rozwój świadomości obywatelskiej oraz budowanie struktur narodowych: „Edukacja może wspomagać rozwój wspólnych kultur oraz wspólnych wartości politycznych. Edukacja może zapoznać młodych ludzi z ideami partycypacji w narodowych procesach politycznych. Ponadto w wielu krajach - szczególnie w socjalnych systemach - edukacja była warunkiem osiągania politycznej mobilizacji oraz poszerzania społecznej świadomości"22.

Warto w tym momencie zauważyć, że państwa rozwijające się, decydując się postawić politykę edukacyjna i naukową jako priorytet, muszą się liczyć ze zmianą społeczną, która może doprowadzić do radykalnych przemian społecznych, szczególnie do wypowiedzenia legitymacji słabej władzy. Z taką sytuacją spotykają się kraje Afryki, gdzie uczelnie często stanowią zarzewie opozycji ${ }^{23}$.

Edukacja niekoniecznie jednak musi przynieść efekty politycznie korzystne, Szirmai zaznacza, że w krajach rozwijających się wąskie klasy wykształconych ludzi oraz same uczelnie często są zarzewiem konfliktów: „W sytuacji konfliktów, różne grupy mogą użyć edukacji w zasilaniu swoich własnych tożsamości i podkreślaniu różnic. Wreszcie, uniwersytety są często siedliskiem opozycji i oporu. W szczególności bezrobocie wśród wykształconych jest czynnikiem destabilizującym" ${ }^{24}$. Jednakże najbardziej politycznie neutralną pozycję zajmuje polityka skupiająca się na kwestiach gospodarczych. Polityka edukacyjna jako priorytet uwidacznia się między innymi w międzynarodowych projektach pomocowych. Programy wsparcia pomocowego, głównie pochodzące $\mathrm{z}$ funduszów pomocowych Unii Europejskiej oraz Stanów Zjednoczonych, silnie inwestują w stypendia oraz programy wsparcia badań. Szirmai pokazuje, że istotne znaczenie powinny odgrywać tutaj nauki bezpośrednio przyczyniające się do wzrostu pozycji na rynkach pracy: „Pomimo rozchodzącego się bezrobocia pośród grupy wykształconych, ciągle istnieją braki w specyficznych zawodach, szczególnie wymagających umiejętności technicznych. Edukacja ciągle zbyt mocno jest zorientowana na humanistykę i nauki społeczne - języki, prawo, historię, socjologię, ekonomię - niż na dyscypliny techniczne, naukowe i rolne"25.

Rozwój definiowany jest jako poszerzanie sfery rynku, wiedzy o ich narzędziach, umiejętności społecznej komunikacji. Można $\mathrm{z}$ tego wnioskować, że pierwszym zobowiązaniem stojącym przed instytucjami wiedzy, w tym także przed uczelniami, jest

\footnotetext{
${ }^{21}$ Dane z UNESCO, cyt. za: A. Szirmai 2005.

${ }^{22}$ Szirmai 2005, s. 249.

${ }^{23}$ Przykładem politycznych problemów między uczelniami a lokalną władzą mogą być państwa Afryki, gdzie uczelnie traktuje się jako ośrodek oporu. Zob. J.A. Nkinyanghi, Students Protest in Sub-Saharian Africa, „Higher Education” 1991, nr. 22..

${ }^{24}$ A. Szimrai 2005, s. 249.

${ }^{25}$ Ibidem, s. 244.
} 
zadanie polegające na redukowaniu nierówności $\mathrm{w}$ dostępie do wiedzy, a poprzez to $\mathrm{w}$ dostępnie do dobrobytu. Bez wątpienia takie właśnie założenie stało u podstaw edukacji masowej, która była zmianą nie tylko tyczącą się samego uniwersytetu, ale także elementem szerszej zmiany społecznej.

Jakie zobowiązania uczelni pojawiają się na tle tego obrazu i do jakiego typu krajów mogą one mieć zastosowanie? Sytuacja ta będzie odnosiła się przede wszystkim do krajów rozwijających się, z elementarnymi problemami edukacyjnymi, takimi jak analfabetyzm. Jednakże naturalnym etapem $\mathrm{w}$ rozwoju będzie zwrócenie uwagi na kolejne kwestie, takie jak rozwijanie własnego potencjału intelektualnego. Zobowiązania publiczne na tym etapie będą wynikały z celów rozwojowych, o czym pisze Szirmai ${ }^{26}$.

\section{UTRZYMANIE DYNAMIKI PAŃSTWA DOBROBYTU W KONTEKŚCIE ZOBOWIĄZAŃ UCZELNI}

Przedstawiony związek instytucji wiedzy $\mathrm{z}$ działaniami ekonomicznymi miał charakter typowo rozwojowy. W krajach wysokorozwiniętych od lat sześćdziesiątych rozwija się kolejny aspekt, tym razem powiązany z procesem, jaki można nazwać utrwalaniem dobrobytu. Procesem tym było pojawienie się masowego kształcenia w szkolnictwie wyższym. Pojawia się ono na rynku szkolnictwa wyższego $\mathrm{z}$ początkiem lat sześćdziesiątych w Stanach Zjednoczonych ${ }^{27}$. Jest to okres tworzenia kształcenia masowego, ale zmiana ta od tamtych czasów kojarzy się z przejściem z poziomu kształcenia elitarnego na masowe. Jednym z kluczowych autorów tego procesu był prezydent Uniwersytetu Berkeley w Kalifornii Clark $\mathrm{Kerr}^{28}$. Z jego osobą wiązano wiele nowych zmian w amerykańskim szkolnictwie wyższym, takich jak przebudowa systemu zarządzania uczelniami, instrumenty wsparcia dla studentów, takie jak pożyczki studenckie. Kerr stał się postacią publiczną w Stanach Zjednoczonych. Był między innymi twarzą jednego $\mathrm{z}$ wydań tygodnika „Time”, na okładce symbolicznie występuje na tle bramy uczelni forsowanej przez masy studentów. Medialność zarówno samego Kerra, jak i jego uczelni (odgrywała ona później jedną z kluczowych ról w procesie rewolucji '68). W swojej - mającej kilka wydań - książce, The Uses of the University, Clark Kerr twierdzi, że rolą publicznego uniwersytetu jest: (1) zwiększenie dostępności utalentowanej młodzieży do studiów wyższych, (2) działania, które doprowadzą uniwersytet do zupełnie nowych formuł działania. W tym sensie Kerr, kierując Uniwersytetem Kalifornii Berkeley, przyczynia się do powstania jego nowej formy - multiwersytetu. W instytucji tej

\footnotetext{
${ }^{26}$ Podoba sytuacja wystąpiła w Polsce po 1989 roku, kiedy procent osób z wykształceniem wyższym kształtował się na poziomie poniżej 10\%, a następnie, w ciągu 20 lat transformacji przeszedł na poziom średniej państw członkowskich OECD, czyli ponad 30\% (zob. OECD, op. cit.). Zjawisko to było połączone $\mathrm{z}$ rozwojem ekonomicznym kraju, gdzie przyrost absolwentów i zainteresowania zdobywaniem wiedzy pokrywał się z rozwojem ekonomicznym.

${ }^{27}$ Boom edukacyjny rozpoczął się w Stanach Zjednoczonych, stąd też nazwa tych procesów w Europie jako „amerykanizacji” szkolnictwa wyższego. Reforma bolońska została przeprowadzona na wzór amerykańskiego szkolnictwa wyższego.

${ }^{28}$ Clark Kerr (1911-2003), pierwszy kanclerz, a 12 prezydent Uniwersytetu Berkeley w Kalifornii.
} 
zmienia się przede wszystkim metoda zarządzania. Na czym ona polega? Clark Kerr wymienia cechy prezydenta uczelni. Są to między innymi: przywódca (a leader), wychowawca (an educator), opiekun (a caretaker), twórca (a creator). ${ }^{29}$. Jak stwierdza autor, z jednej strony uczelnia musi spełniać swoją dawną misję: poszukiwania prawdy, z drugiej strony zaś powinna się stać narzędziem, które będzie wspomagało innowatorów, poszukiwało nowych zastosowań wiedzy oraz powodowało zjawisko nazywane knowledge explosion. Można powiedzieć, że w tym czasie dokonuje się istotna zmiana ekonomiczno-kulturowa, której Kerr był w pełni świadomy. Wiedza staje się czynnikiem zmiany społecznej, a uniwersytet instytucją nie tylko kształcenia, ale także odgrywa on nową rolę, staje się instytucją odpowiadającą na społeczne zapotrzebowanie, zarówno „fabryką wiedzy”, jak i miejscem lokacji jej absolwentów w wyższej klasie społecznej. Kerr podaje: „Podstawową rzeczywistością dla uniwersytetu jest rozprzestrzeniająca się akceptacja, że nowa wiedza jest najbardziej istotnym czynnikiem wzrostu ekonomicznego i społecznego. [...] wiedza może być najbardziej wpływowym elementem naszej kultury, wpływająca na wzrost i upadek zawodów, a nawet klas społecznych, regionów i narodów"30.

„Multiwersytet” na nowo definiuje rolę uczonych. Uczony to nie tylko akademik skupiony na wykładach i badaniach, ale to także menadżer badań, który potrafi zdobywać fundusze i odpowiednio nimi zarządzać. Wzrost zewnętrznej i wewnętrznej konkurencji doprowadza do nowych form edukacji i walki o studenta, co w masowym systemie kształcenia staje się standardem. Można powiedzieć, że idea multiwersytetu Kerra dokonuje instytucjonalizacji zmiany publicznych zobowiązań uniwersytetu w świecie Zachodu. Jeden z podstawowych jej wymiarów kształtowany jest przede wszystkim poprzez działania względem swojego otoczenia: gospodarczego, regionalnego czy wreszcie skupionego wokół potrzeb społecznych. Multiwersytet przypomina korporację produkującą towary i usługi. Jego misja zostaje zdefiniowana przede wszystkim przez cele ekonomiczne.

W tym modelu zobowiązania publiczne uniwersytetu zostają ograniczone do obsługi sponsorskiej. Sytuacja ta kreuje utylitarny model działania, gdzie uniwersytet staje się istotnym elementem w grze rynkowej, jedną z części łańcucha produkcji. Jego zobowiązania stają się wówczas jasne, będzie to raczej moment zmiany zobowiązań, tak dzieje się to w korporacji ${ }^{31}$.

Warto jednak zauważyć, że ekonomiczne zorientowanie zobowiązań uniwersytetu niekoniecznie przekłada się na jego publiczną misję. Powstaje pytanie: czy w przejście do kształcenia masowego - a było to jedną z jego publicznych misji i celów Clarka Kerra pojawiło się zmniejszenie nierówności społecznych? Wzrost odsetka studiujących w amerykańskim szkolnictwie wyższym rzeczywiście był rewolucyjny. Pytanie to staje się podstawą krytyki Christofera Newfielda w jego książce Unmaking Public University, w której pokazuje znaczącą rolę uczelni publicznych w tym procesie: „W ciągu pięciu lat od

${ }^{29}$ C. Kerr, The Uses of the University, Harvard University Press, Cambridge 2007, s. 23.

${ }^{30}$ Ibidem, s. iv.

31 „Korporacja” w odniesieniu do uczelni ma różne znaczenia. Trzeba rozróżnić między klasycznym rozumieniem korporacji (zob. J. Sójka, op. cit.) od korporacji biznesowej w takim sensie, w jakim zostało to użyte w modelu multiwersytetu - jako korporacji gospodarczej. 
zakończenia II wojny światowej odsetek studiujących na uczelniach potroił się z 26500 do 79 500, a w 1960 przekroczył 300 000. W kraju [Stanach Zjednoczonych - C.K.], odsetek studentów wzrósł do 78 procent w 1940 roku, 31 procent w 1950 roku i 120 procent w roku 1960 "32. Problem polega jednak na tym, że efekt ten niekoniecznie jest wynikiem jedynie komercjalizacji uczelni. W poprzednim punkcie była mowa o tym, że liczba studiujących zwiększa się w krajach rozwijających się, które przyjmują zachodni model gospodarki, ale także odpowiedniej polityki państwa. Kwestia wzrostu bezwzględnej liczby studiujących nie zależy zatem jedynie od procesów urynkowienia studiów, ale trendów w polityce publicznej, gdzie państwa zaczęły silnie inwestować $\mathrm{w}$ tę sferę, na przykład poprzez tworzenie zachęt w postaci kredytów studenckich. Należy się zastanowić jednak, czy nierówności społeczne i kulturowe na uczelniach rzeczywiście zmieniły się jest na tyle istotnie, że pozwala to przynajmniej częściowo odpowiedzieć, czy utylitarny zwrot był zmianą skorelowaną ze zmianą społeczną, czy też jedynym beneficjentem była uczelnia i współpracujące $z$ nią otoczenie? Odpowiadając na tę kwestię, Christopher Newfield zauważył, że odsetek studentów afroamerykańskich do białych w Stanach Zjednoczonych nie zmienił się znacząco: o ile w roku 1940 biali stanowili $97 \%$ wszystkich studentów, to w roku 1995 było ich $80 \%{ }^{33}$. Jeśli zatem przyjąć, że najbardziej uboga klasa społeczeństwa nie miała dostępu do instytucji awansu społecznego w połowie XX wieku, to sytuacja ta niewiele zmieniła się pod koniec tego wieku. Zdaniem autora uczelnia nastawiona na realizację celów ekonomicznych wypełniała przede wszystkim cele klasowe: „po 1890 roku kształcono około milion absolwentów rocznie. Absolwenci ci przenosili technologiczne i kulturowe kształcenie do centralnej pozycji amerykańskiej ekonomii” ${ }^{34}$. Tym samym zobowiązania kulturowe uczelni zorientowane były przede wszystkim na klasę średnią - jak pokazuje Newfield: antykomunistyczną, technokratyczną oraz odtwarzającą dawne podziały klasowe i społeczne, w tym „nieformalną segregację przeeksploatowanych rasowo zawodów”35.

Krytyka ze strony Newfielda pokazuje znaczący problem: $\mathrm{z}$ jednej strony udoskonalenie komercyjne nie spowodowało znaczącego zmniejszenia się nierówności, a $\mathrm{z}$ drugiej strony utrwaliło układ klasowy, w jakim dostępność i użyteczność została ograniczona jedynie do danej klasy społecznej. Przekładając te wnioski na język zobowiązań uniwersytetu, komercjalizacja nie spowodowała wytworzenia dostatecznych mechanizmów solidarności i nie spowodowała rozszerzenia inkluzywności amerykańskiego uniwersytetu.

Rozważając tę dyskusję, należy zwrócić jednak uwagę na specyficzny amerykański kontekst, według którego edukacja wyższa w Stanach Zjednoczonych inaczej jest postrzegana niż w Europie. W Stanach Zjednoczonych nie należy ona do „dóbr publicznych” i „praw” (jakkolwiek w wyborach w 2012 roku prezydent Obama zadeklarował, że edukacja powinna być traktowana właśnie jako dobro publiczne). Edukacja to element „dobra prywatnego”, który ma swoją cenę i podlega regułom rynkowym oraz regułom tradycyjnej wymiany dóbr.

\footnotetext{
${ }^{32}$ Ch. Newfield, op. cit., s. 28.

${ }^{33}$ Ibidem.

${ }^{34}$ Ibidem, s. 30.

${ }^{35}$ Ibidem, s. 29.
} 
Kwestię tę precyzyjnie dookreśla Marek Kwiek w książce Transformacje uniwersytetu: „W krajach anglosaskich [...] edukacja tradycyjnie nie mieści się $\mathrm{w}$ ogólnym sensie terminu „państwo dobrobytu” (a może raczej właśnie w tej tradycji pozostaje tłumaczenie « państwo opiekuńcze»): natomiast w Europie kontynentalnej jak dotąd nie zaistniała na taką skalę jak w krajach anglosaskich [...] praktyczna restrukturyzcja - bądź choćby teoretyczne myślenie o niej - instytucji edukacyjnych w ramach ciągle jeszcze ostrożnego definiowania na nowo przyszłych ról państwa w społeczeństwie i gospodarce" ${ }^{36}$.

Rozważając zobowiązania ekonomiczne, można powiedzieć, że polityka uczelni amerykańskich polega na takich działaniach, które podniosą atrakcyjność sylwetki absolwenta, jego umiejętności, wiedzę i możliwości zaistnienia w systemie ekonomicznym. W wydaniu europejskim działania uczelni są połączone ze zmianą publicznej polityki. Wydaje się jednak, że obecnie amerykanizacja się poszerza, szczególnie w czasach kryzysu. Coraz silniejsze wezwanie do innowacyjności i kreatywności uczelni zmusza ją do coraz większych inwestycji, których budżety publiczne nie są w stanie unieść. Model edukacyjny sprzężony jest $\mathrm{z}$ celami państw, ale te wymagają coraz większych nakładów, co powoduje paradoksalną sytuację, że uczelnie coraz bardziej będą zależne od państwa i jego polityk, ale jednocześnie finansowo będą musiały znaleźć własne źródła przychodów. W tym miejscu dochodzimy do problematyki konceptualizacji samych zobowiązań. Stuart White w rozdziale „Ethics” w książce Oxford Handbook of Welfare State wskazuje na następujące różnice: „Kluczowe pytanie jest takie, jakiego prawa tyczą się prawa socjalne. Pewnie prawa społeczne są prawami po prostu do określonych zasobów [...]. Lecz prawa społeczne mogą być rozumiane alternatywnie, jako prawa do rozsądnego dostępu do odpowiednich zasobów"37.

Czy „rozsądnym dostępem do zasobów” będzie sama możliwość edukacji, czy też edukacji skutecznej, odpowiadającej założeniom doskonałości, która doprowadzi absolwenta do równego startu? Pytanie to zostaje również przeniesione na wymiar instytucjonalny: na ile uczelnia jest autonomiczna, aby móc kształtować dostęp do zasobów? Trzymając się wywołanego u Newfielda przykładu dostępności Afroamerykanów, akcje afirmatywne, wyrównujące szanse studentów ze zmarginalizowanych środowisk etnicznych idą w kierunku sprawiedliwszego dostępu do zasobów. Odwrót od czysto merytoktratycznej selekcji ma wielu krytyków, jednakże pokazuje on na zmianę, jaka pozwala gorzej uposażonym zrównać szanse w konkurencyjności. Nie wchodząc w tym miejscu w problem oceny wywołanego wcześniej przypadku amerykańskiego, poszerzenie oceny kwalifikacyjnej kandydata daje sposobność do poszerzenia puli dóbr, a tym samym odpowiada na warunek solidarności. Tego rodzaju problem społeczny pojawia się zresztą $w$ innych częściach świata. Andre Beteille, $z$ Uniwersytetu w Delhi w książce Universities at the Corssroads pokazuje, że w krajach rozwijających się uczelnie przede wszystkim mają zobowiązania publiczne, niekoniecznie bezpośrednio skorelowane. Beteille wskazuje, że rolą instytucji wiedzy jest tworzyć inkluzywne społeczeństwo. Jego antypody to społeczeństwo bez dostępu do wiedzy,

\footnotetext{
${ }^{36}$ M. Kwiek, op. cit., s. 346.

${ }^{37}$ S. White, Ethics, [w:] F. Castels, S. Leibfried, J. Lewis, H. Obinger, Ch. Pierson, The Oxford Handbook of Welfare State, Oxford University Press, Oxford 2010, s. 21.
} 
pozbawione możliwości akcesu do awansu społecznego: „Akces do wyższej edukacji oraz wyższych zawodów menadżerskich i administracyjnych pozostaje wciąż bardzo strzeżony. Jest ograniczenie, które pojawia się, gdy zaczyna się myśleć o niepowodzeniu Indii w stawaniu się społeczeństwem inkluzywnym"38. W jaki sposób uczelnie mogą osiągać ten cel? $\mathrm{Na}$ wstępie, Beteille twierdzi, że „Nieprawdą jest, że otwieranie kolejnych uniwersytetów i kształcenie absolwentów automatycznie spowoduje większą równość" ${ }^{39}$. Konstatacja Beteille'a, skądinąd praktyka uczelni świata Zachodu i Dalekiego Wschodu wskazuje, że kształcenie niekoniecznie musi się przekładać na wyrównywanie różnic społecznych. W tym znaczeniu zmiana kulturowa niekoniecznie musi się przekładać na zmianę ekonomiczną, jeśli nie będzie spełnionych warunków dobrego funkcjonowania państwa. Prawdopodobnie tego typu problem występuje nie tylko w społeczeństwach kastowych, ale także w krajach cierpiących na korupcję, niesprawny system administracyjny oraz zmonopolizowaną strukturę dystrybucji dóbr.

Rekapitulując podrozdział: publiczne zobowiązanie uniwersytetu w sensie ekonomicznym będzie oznaczało przejście na poziom jego zaangażowania w ekonomicznym systemie. Będzie to zobowiązanie polegające przede wszystkim na wzmacnianiu potencjału rozwojowego państwa. Warto jednak mieć na uwadze, że uczelnie nie tylko przyczyniają się do zmiany ekonomicznej, ale także mają silny wpływ na kształtowanie sfery kulturowej, o czym traktują ich kolejne zobowiązania.

\section{KULTUROWE UWARUNKOWANIA PRZEMIAN SZKOLNICTWA WYŻSZEGO}

Instytucje wiedzy są zarzewiem moralnej zmiany, a obecnie krajach rozwijających się są również zarzewiem protestów studenckich ${ }^{40}$. Uczelnie w znacznej mierze przyczyniły się do rewolucji obyczajowej $\mathrm{w}$ latach sześćdziesiątych $\mathrm{XX}$ wieku, podobnie $\mathrm{w}$ Polsce były ośrodkami ruchów antyrządowych ${ }^{41}$. Bez wątpienia jednak polityka edukacyjna nie tylko się opłaca, gdyż jest motorem społecznej zmiany, ale także pozwala pełnić uczelni dodatkowe funkcje obywatelskie, takie jak krytyka społeczna. W tym miejscu można zdefiniować nowe zobowiązanie uniwersytetu: polegałoby ono na formowaniu dojrzałych i krytycznie myślących obywateli, którzy w przyszłości będą pełnili funkcje elit społecznych. Taka rola uczelni w sposób niebudzący kontrowersji pojawia się w krajach Zachodu, jednakże w krajach rozwijających się, szczególnie pozaeuropejskich, rola ta może być istotnie kwestionowana. Bez wątpienia jednak zobowiązanie to wymaga autonomii uczelni. Społeczność akademicka musi zachować swoją indywidualność i pewną izolację szczególnie od świata polityki, lecz nie po to, aby od niej uciekać, lecz aby skuteczniej ją poprawiać. Innymi słowy byłaby to

${ }^{38}$ A. Beteille, Universities at the Crossroads, Oxford University Press, New Delhi 2010, s. 97.

${ }^{39}$ Ibidem, s. 4.

${ }^{40}$ Zob. Ph. Altbach, Students Political Activism, [w:] idem, Comparative Higher Education, Ablex Publishing, Norwood 2006.

${ }^{41}$ C. Kościelniak, Uniwersytet i aktywizm studencki wobec obywatelskiego niepostuszeństwa, [w:] C. Kościelniak, J. Makowski, Wolność, równość, uniwersytet, Instytut Obywatelski, Warszawa 2011. 
ingerencja $\mathrm{w}$ sferę społeczno-polityczną z innej perspektywy niż polityczna. Patrząc na rolę uniwersytetów z perspektywy globalnej, taka rola wydaje się ciągle potrzeba. Ponownie warto powrócić do przykładu Clarka Kerra (nota bene zdymisjonowanego przez gubernatora Reagana za nie poradzenie sobie ze studenckimi protestami). Sytuację na University of California Berkeley Newfield przedstawia następująco: „Uniwersytet stał się miejscem otwartych buntów o prawa obywatelskie i wolność słowa, a także miejscem opozycji wobec liderów biznesowych i politycznych, przeniósł do kraju dyskusję nad problemami, począwszy od nierówności rasowych, poprzez zanieczyszczenia powietrza, a skończywszy na wojnie $\mathrm{w}$ Wietnamie" ${ }^{42}$. Wynika z tego, że zobowiązania uczelni wobec społeczeństwa obywatelskiego są jednym z wyznaczników misji uniwersytetu.

Kolejnym wyzwaniem jest globalizacja i multikulturowość, która zmienia charakter samego uniwersytetu. Przemiany te opisuje to Martha Nussbaum w ważnych książkach Not for Profit oraz Cultivating Humanity. Problemem staje się global citizenship, czyli multikulturowe społeczeństwo oparte na uwspólnionych praktykach społecznych. Uczelnie powinny zmieniać się - szczególnie swój proces edukacyjny - w kierunku instytucji poszerzających różnorodność edukacyjną: ,Jednym z błędów pozostaje fałszywe przekonanie, że różnorodność edukacyjną można przekazać tylko na podstawie jednej tradycji i że tylko ona zdolna jest do samokrytycyzmu oraz uniwersalnych aspiracji" ${ }^{43}$. Celem tego działania jest poszerzenie instytucjonalnych kompetencji kulturowych uniwersytetu o ludzi i instytucje z poza kultury Zachodu. Proces ten sam w sobie wymagałby osobnej dyskusji, bez wątpienia jednak wiele praktyk społecznych, przede wszystkim związanych $\mathrm{z}$ handlem międzynarodowym.

Poszerzanie kompetencji multikulturowych polegałyby na włączeniu innych punktów widzenia do curriculów, które zmienią się o tyle, o ile zmieni się sama uczelnia. To jednak może nastąpić wtedy, gdy uczelnie przyjmą na siebie zobowiązanie za kwestie globalne. Nussbaum wymienia tutaj: studia nad poza zachodnimi kulturami, studia afroamerykańskie (w Europie Zachodniej ich odpowiednikiem będą studia nad problemem kolonializmu), wreszcie będą to kwestie religii. Nowa liberalna edukacja ma za zadanie znalezienie momentu, jaki będzie kontynuacją „kultywowania humanitas”, co ma - zdaniem autorki - bezpośredni wpływ na jakość życia obywateli. Zadanie to przyczynia się zarówno do lepszego zrozumienia kwestii podstawowych, ale jednocześnie nie jest oderwane od praktyki ekonomicznej, która pozbawiona sfery kulturowej nie będzie działała równie sprawnie.

Martha Nussbaum występuje w roli liberalnego obrońcy roli humanities na uniwersytecie, w którym już dokonał się zwrot przedsiębiorczy. Normatywnym punktem wyjścia dla Nussbam pozostaje zsekularyzowane i multikulturowe społeczeństwo, dla którego głównym spoiwem pozostaje ekonomia. Nie sposób jednak nie zauważyć, że nawet w tej wizji uniwersytet nie wyrzeka się roli kulturotwórczej. Oznacza to, że pozostaje on instytucją publiczną operującą jakąś wizją antropologiczną, wizją wspólnoty, czy wreszcie wizją wartości, jakie miałby realizować. Pod adresem strategii Nussbaum można by

\footnotetext{
${ }^{42}$ C. Kerr, op. cit., s. 28.

${ }^{43}$ M. Nussbaum, Cultivating Humanity, Harvard University Press 2003 s. 11.
} 
sformułować szereg uwag krytycznych oscylujących głównie w wymiarze słabości liberalnego uzasadnienia wspólnot - dyskusji znanej i od wielu dekad prowadzonej w filozofii politycznej. Pomimo tego Nussbaum pokazuje, że element kulturowy jest nieodwoływalny jeśli chcielibyśmy zachować jakąkolwiek tożsamość uniwersytetu i jego zobowiązań wobec społeczeństwa.

Znacznie głębsze rozumienie ról kulturowych proponują jednak zwolennicy konserwatywni, m.in. Sommerville i MacIntyre. Sommerville w The Decline of Secular Universty dostrzega zagrożenie wykluczenia $\mathrm{z}$ agendy edukacyjnej uczelni istotnych kwestii oraz pytań egzystencjalnych, które kształtują człowieka i jego tożsamość. MacIntyre idzie jeszcze dalej wskazując, że obecnie dochodzi do rozbicia jedności uniwersytetu. Kwestia ta wyznacza kolejne zagadnienia wykraczające poza niniejszy tekst, jak rola humanistyki w kształceniu zawodowym, zmiany modeli uniwersytetu w kontekście jego kulturowej misji, czy też wpływ sfery wartości i religii na kształtowanie się agendy uniwersytetu. Istotą konserwatywnej krytyki jest sprzeciw wobec uczelni w modelu korporacyjnym traktowanej jako dostarczyciela patentów, zawodowych umiejętności prowadzącego komercjalizację badań i procesów kształcenia. W tym przypadku rolą uniwersytetu będzie uczenie myślenia krytycznego, samodzielnego; absolwent nie tylko ma być specjalistą w swojej dyscyplinie, ale także aktywnym i dojrzałym obywatelem, świadomym swojej roli społecznej. W tej perspektywie bardzo złudne wydaje się założenie, że np. technologią można zastąpić programy kształcenia zaangażowanego w kształtowanie świadomości obywatelskiej, czy etycznego przebudzenia.

\section{WNIOSKI}

Celem tekstu było szkicowe ukazanie dwóch możliwych perspektyw w celu opisania zobowiązań uniwersytetu. $Z$ jednej strony była to perspektywa ekonomiczna, która przyniosła nowe wyzwanie dla misji uczelni i skierowała tę instytucję $w$ stronę uniwersytetu przedsiębiorczego. $\mathrm{Z}$ drugiej strony była to perspektywa kulturowa, opierająca się na emancypacyjnych i globalnych wyzwaniach współczesnego świata. W obu wypadkach uczelnia ma określoną swoją rolę. W obu wykracza poza swoje klasyczne funkcje: kształcenia i prowadzenia badań, a jej celem będzie forma integracji społecznej. Konkluzja, jaka wyłania się $\mathrm{z}$ naszkicowanego tekstu, jest taka, że dwóch typów zobowiązań - kulturowych i ekonomicznych - nie sposób ani od siebie rozdzielić, ani też ich sobie przeciwstawiać. Uniwersytety nie muszą rezygnować ze swojej misji ekonomicznej, aby angażować się w nowe zobowiązania publiczne. Jak twierdzą jednak krytycy „przedsiębiorczego zwrotu” współczesnego uniwersytetu, istotne było uświadomienie sobie społecznej roli uczelni w społeczeństwie oraz uchronienie go przed zatraceniem jego pierwotnej misji, jaką było kształcenie. Artykuł niniejszy ma charakter wstępnego określenia problemu, w dalszym procesie badawczym należałoby ustalić - na przykład poprzez badanie przypadków - w jaki sposób zmiana misji wyznacza nowe trajektorie rozwojowe poszczególnych uczelni oraz polityk szkolnictwa wyższego na poziomie państw i regionów. Kolejnym zagadnieniem jest 
kwestia kulturowych uwarunkowań transformacji polityk szkolnictwa wyższego, społecznej akceptacji dla utrzymania nakładów na szkolnictwo wyższe oraz uświadomienia sobie konsekwencji społecznej w przejściu na masowy poziom kształcenia na poziomie trzeciego stopnia.

\section{LITERATURA}

[1] Altbach Ph., Students Political Activism, [w:] idem, Comparative Higher Education, Ablex Publishing, Norwood 2006.

[2] Arbo, P. Benneworth, P., Understanding the Regional Contribution of Higher Education Institutions, Paris: OECD, 2007.

[3] Beteille A., Universities at the Crossroads, Oxford University Press, New Delhi 2010.

[4] Busemeyer R.M., Nikolai R., Education, [w:] F. Castels, S. Leibfried, J. Lewis, H. Obinger, Ch. Pierson, The Oxford Handbook of Welfare State, Oxford University Press, Oxford 2010.

[5] Clark B., Creating Entrepreneurial University, Pergamon Press, New York 1998.

[6] Dąbrowa-Szefler M., Jabłecka J., Szkolnictwo wyższe w Polsce. Raport dla OECD. MNiSW, Warszawa 2007.

[7] Kerr C., The Uses of the University, Harvard University Press, Cambridge 2007.

[8] Kwiek M., Transformacje uniwersytetu, Wydawnictwo UAM, Poznan 2010.

[9] Kościelniak C., Uniwersytet $i$ aktywizm studencki wobec obywatelskiego niepostuszeństwa, [w:] C. Kościelniak, J. Makowski, Wolność, równość, uniwersytet, Instytut Obywatelski, Warszawa 2011.

[10] Kościelniak, C. "Does European higher education policy could be a political tool for solidarity with South?", w: 10 years of Slovak Aid, Pontis, Bratislava 2013.

[11] MacIntyre, A., God, Philosophy, Universities, Rowan\&Littlefield, Plymouth 2009.

[12] Newfield Ch., Unmaking Public University, Harvard University Press, Harvard 2007.

[13] Nkinyanghi J., Students Protest in Sub-Saharian Africa, „Higher Education” 1991, nr 22.

[14] Nussbaum M., Not for Profit, Princeton University Press, Princeton 2010.

[15] Nussbaum M., Cultivating Humanity, Cambridge University Press, Cambridge 2003.

[16] OECD, Education at Glance 2011, Paris 2011.

[17] Sen A., Wolność jako rozwój, Zysk i Ska, Poznań 1998.

[18] Sławek T., Antygona $w$ świecie korporacji. Rozważania o uniwersytecie $i$ czasach obecnych, Wydawnitwo Uniwersytetu Śląskiego, Katowice 2002.

[19] Sommerville, J., The Decline of Secular University, Oxford Univrsity Press 2005.

[20] Sójka J., Społeczna odpowiedzialność uniwersytetu, [w:] J. Sójka, A. Grzegorczyk, Fenomen uniwersytetu, Wydawnictwo UAM, Poznań 2008.

[21] Sporn B., Adaptive University Structures, „Higher education Policy” 1999, nr 54.

[22] Sustainability and Higher Education in Central and Eastern Europe, red. M. Adomssent, I. Otte, VAS, Bad Homburg 2013. 
[23] Szirmai A., The Dynamic of Socio-Economic Development, Cambridge University Press, Cambridge 2005.

[24] Twardowski K., O dostojeństwie uniwersytetu, reprint, Wydawnictwo UAM, Poznań 2011.

[25] White S., Ethics, [w:] F. Castels, S. Leibfried, J. Lewis, H. Obinger, Ch. Pierson, The Oxford Handbook of Welfare State, Oxford University Press, Oxford 2010.

\section{THE PUBLIC ROLES OF THE CONTEMPORARY UNIVERSITY: BETWEEN THE CULTURAL AND ECONOMIC DUTIES}

The main aim of the paper is an analysis of the transformation of the public duties of universities focused on two directions: cultural and economic ones. Since 50s of XX century Western universities underwent the "entrepreneurial turn". Their mission was centred to the production and commercialization of knowledge. Meanwhile knowledge institutions take an important role in creating the welfare society both in education and research. The "entrepreneurial turn" begins from the reforms introduced by Clark Kerr at University of California Berkeley. The critics of the "entrepreneurial turn" point out that it causes a deep crisis of the public duties of universities and pushes them to the narrow, economic mission only. Both liberal and conservative critics agree that the role of arts and humanities is crucial in contemporary curricula. Humanities should support and complete the professional education in different disciplines. The paper considers the potential of the increasing of the capacity of the public duties of universities, like a sustainable development, the policy of equality and - using the term of Martha Nussbaum - deep involvement of the knowledge institutions in the processes of global citizenship. The public duties of universities bridges the cultural issues with economic. Commitments of the university to the public sphere combine cultural issues with economic ones, e.g. by increasing of the access to higher education. The conclusion of the paper is that, both economic and cultural duties should be synchronized.

Keywords: university, public duties, social development

DOI:10.7862/rz.2013.hss.44

Tekst złożono w redakcji: wrzesień 2013.

Przyjęto do druku: marzec 2014. 